\title{
Distribution and monitoring of power and mechanisms to increase the efficiency of power in Shiite political thought
}

\section{Distribución y seguimiento del poder y mecanismos para aumentar la eficiencia del poder en el pensamiento político Shiite}

\author{
Hassan Abbaszadeh
}

$\mathrm{PhD}$ student in Theology, Jurisprudence and Fundamentals of Islamic Law, Islamic Azad University, Mashhad Branch, Iran

\section{Hossein Ahmari}

Member of the Theology, Jurisprudence and Fundamentals of Islamic Law group Islamic Azad University of Mashhad Iran Branch

\section{Mohammad Reza Javaheri}

Member of the Theology, Jurisprudence and Fundamentals of Islamic Law Department, Islamic Azad University, Mashhad Branch, Iran

*Correspondence Cite as: 
Summary

The results of this study, due to the many ambiguities in the field of power in Islam, can be considered by government organizations such as the Guardian Council and researchers in the fields of jurisprudence and law, natural and legal persons who somehow deal with sources of power, and students and professors of political science. And rights to be placed. Depending on the subject of the research, the method of collecting materials in an analytical and descriptive manner and by studying valid sources in the library and, if possible, the interview method will be on the agenda so that first the desired sources are studied and after analysis, In the end, this research aims to achieve results and make suggestions for improving the current situation; Therefore, first the required resources from various sources of presence in the library, digital libraries, existing software such as comprehensive Ahl al-Bayt and Shiite history and existing articles, treatises and dissertations, selected and after studying and separating the required materials, receipts Necessary from the required resources and then as a complete research, its compilation will be completed. The present study will have a new approach to all aspects of power in Shiite political thought and the author will try to have a comprehensive look at the jurisprudential principles of this issue based on Quranic arguments, narration, sayings of jurists and rational arguments.

Keywords: Shiite power, power and politics, power and politics, Shiite political thought. Concept of monitoring

\section{Resumen}

Los resultados de este estudio, debido a las muchas ambigüedades en el campo del poder en el Islam, pueden ser considerados por organizaciones gubernamentales como el Consejo de Guardianes e investigadores en los campos de la jurisprudencia y el derecho, personas físicas y jurídicas que de alguna manera tratan con fuentes de poder, y estudiantes y profesores de ciencias políticas. Y derechos a colocar. Dependiendo del tema de investigación, el método de recolección de materiales de manera analítica y descriptiva y mediante el estudio de fuentes válidas en la biblioteca y, si es posible, el método de entrevista estará en la agenda para que primero se estudien las fuentes deseadas y luego análisis, al final, esta investigación tiene como objetivo lograr resultados y hacer sugerencias para mejorar la situación actual; Por lo tanto, primero los recursos requeridos de diversas fuentes de presencia en la biblioteca, bibliotecas digitales, software existente como Ahl al-Bayt y la historia chií completa y artículos existentes, tratados y disertaciones, seleccionados y después de estudiar y separar los materiales requeridos, recibos Necesarios a partir de los recursos requeridos y luego como una investigación completa, se completará su compilación. El presente estudio tendrá un nuevo enfoque de todos los aspectos del poder en el pensamiento político chí́ta y el autor intentará tener una mirada integral a los principios jurisprudenciales de este tema a partir de argumentos coránicos, narraciones, dichos de juristas y argumentos racionales.

Palabras clave: poder chií, poder y política, poder y política, pensamiento político chií. Concepto de seguimiento 


\section{Introduction}

In Islamic thought, Shia; He sees the continuity of divine sovereignty in the face of the Imamate and considers the intrinsic aspects of politics as fundamental and considers it as a basic ammunition of religion and, of course, a fundamental and research thing. The human mind has always been involved in recognizing the various dimensions and angles of political power, and there have always been people seeking answers to the question of who rules and how. Having power is one of the basic conditions for the success of any government in preventing chaos and law enforcement, and in creating security and preventing the aggression of foreign enemies. Power is fully exercised when it has legitimacy. In the realm of political science, there are mostly vague, ambiguous, interpretable words; But it is rare to find a term or phrase that is as ambiguous as the word power. Therefore, explaining the principles and concept of power and monitoring it in the Islamic government and proving its necessity and mechanisms for increasing and efficiency of power for the Islamic society is one of the vague and unknown points of this issue. The results of this study due to the many ambiguities in the field of power in Islam can be considered by government organizations such as the Guardian Council and researchers in the fields of jurisprudence and law and natural and legal persons who somehow deal with sources of power and students and professors of science. Be political and legal.

The Islamic Revolution, with the help of God Almighty, led to the victory of the Supreme Leader in Iran, and its flag was hoisted amidst the wonder and infertility of friend and foe. In the continuation of its growing movement, its duty is to defend the unity of Islam and Muslims and to preserve the values of the revolution. On the other hand, its duty is to explain and adapt the issues of society (governmental, political, social and judicial) to the commands and laws of Islam. One of the sides of power in the Islamic government is its duty to formulate laws and implement them based on well-documented and clear jurisprudential principles in order to meet the needs of the Islamic society. In this research, the author will try to analyze the mechanism of monitoring and its effectiveness in order to prove that it can be moved towards its effectiveness by careful monitoring and design of monitoring programs. On the other hand, considering that most of the books and articles done on this subject, each of them had analyzed the jurisprudential principles of power from a specific angle. The author will try to comprehensively and coherently take the power that is derived from the Qur'anic arguments and the narration of the jurists and rational arguments; Discuss.

\section{Literature and theoretical foundations of research}

Power is one of the major and at the same time complex concepts of social sciences that despite its importance, less thinkers have agreed on the nature, function and definition of this concept; therefore, different schools of thought according to their different epistemology, methodology and ontology They have explained the nature and concept of power. Islam as a religion of monotheism, which has a universal scope, in explaining, defining and presenting political concepts and approaches has not been satisfied only with their material propositions. The extraterrestrial view of Islam and the existence of propositions such as happiness, The guidance of divine legitimacy, divine purpose, human dignity, etc. in the intellectual paradigm and works of Islamic thinkers has led to their definitions of political concepts with the definitions given by Western thinkers of political science around these words. Be different and sometimes conflicted. 
What constitutes the common chapter of Islamic thinkers, jurists and philosophers, and especially the Shiites, in explaining and presenting the concept of power, is the immaterial dimension of this concept and the originality that they place on the transcendent power of power. With the former thinkers, while explaining the theory of political jurisprudence and its various concepts, including the concept of power, they were able to use it in the administration of society and government and include it in the law of the Islamic Republic of Iran.

The concept of power

- Power: The word power is originally derived from the word qadr in Arabic meaning the full capacity and ultimate limit of anything. And in Persian, power has been defined as a source in the sense of ability and being able and as a noun in the sense of ability (Dehkhoda Culture page .......) Ragheb Esfahani in expressing the concept of power says: Power whenever in describing man Used means a state with which a person can do something successful It becomes. But if it is used as a description for God, it means that he is unable to do anything (Al-Mufradat Fi Al-Faz Al-Quran, Isfahani, Hussein Ibn Muhammad Ragheb)

- Power in the term: In the books of jurists, the word power is not explicitly stated, but words that convey the meaning of power, such as (Sultan) (ruler) (king), (governor), (Makna) and caliph are mentioned, so the meaning of all this The words in the terminology of the jurists are the power of the Prophet and the pure Imams during their presence and the jurists during their absence; That is, they have power and domination in the province of prudence and political administration and the implementation of divine commandments. In the sources of jurists which is power and tradition; Power has also been interpreted as a province. As the Qur'an refers to the nature of the power of the Prophet and his successors with the two words guardianship and obedience (verse 55 of Surah Ma'idah) (The relationship between power and justice in political jurisprudence, Ghulam Sarwar Akhlaqi, p. 22).

Political Thought: The word means thought, reflection, contemplation, possession of property, keeping, protection and maintenance, protection, ruling on the subject. (Dehkhoda culture) and in the term: political thought which is the most important part of political knowledge; It is a set of philosophical beliefs that are directly related to the management of society. Political thought, then, refers to a set of opinions and ideas in the political field that have reasonable goals and by determining the necessary tools to achieve achievable goals, have a kind of internal coherence and logic and in response to specific questions and riddles in the field. Political life comes into play. (Political Thought of Ayatollah Khamenei Mohammad Mehdi Ismaili p. 19). Also, political thought, in its general and broad sense, includes any kind of thinking and view about the principles, dimensions, application of components and factors affecting political power in society. (Cultural life and political thought of Shiites from the fall of Baghdad to the rise of Safavids, Mohsen Al-Weeri, p. 361). According to another definition, political thought is a set of ideas and thoughts that are related to power and its purpose is to study the past life of human beings and provide a model and a way to transform a better and more desirable society. (Muslim Political Thought, Morteza Shiroodi Volume 1 Page 15)

Politics: The word means ruling over the subjects and managing the affairs of the country, ruling, presiding, managing the internal and external affairs of the country (Farhang Moin, vol. 2, p. 1966). Politics is the uprising against the thing. Peace is action and doing something according to its expediency (Language of the Arabs, Ibn Manzoor, Abu al-Fadl, Jamal al-Din, Muhammad ibn Makram, vol. 6, p. 108). 
Politics in the term: The late Saduq, while visiting the great community, considers politics to mean guiding people to worldly and otherworldly happiness; Because the Imams are in charge of material and spiritual affairs. Imams are mentioned as politicians in the pilgrimage of the large community. (Peace be upon you or the Ahl al-Bayt al-Nabawah and Saseh al-Ibad)

The late Majlisi, while quoting a hadith from Imam Sadegh, considers politics as the management of the material and spiritual affairs of the people and the development of cities. (We are Akhyar Al-Dahr and Nawamis Al-Asr and we are Saseh Al-Ibad and Saseh Al-Balad) (Bihar Al-Anwar, Isfahani, Majlisi II, Mohammad Baqir Ibn Mohammad Taqi, vol. 26, p. 259). Imam Khomeini considers politics to mean the relationship between the nation and the governments and the guidance of the society towards what is in their interests, as well as providing the ground for the worldly and otherworldly happiness of the people and leading them in a direct way. (Sahifa Imam, Al-Sayyid Ruhollah Mousavi Al-Khomeini, vol. 13, p. 432).

Shia: Dictionaries have mentioned the following meanings for the word Shia from the root of Shia:

Sect, party and group of followers, companions and supporters of the ummah, friends and companions and collaborators of reinforcers and disseminators (Al-Ain, Farahidi, Khalil Ibn Ahmad, vol. 2, pp. 190 to 193), P. 235). Literally, Shiite refers to a group that follows or accompanies or cooperates with another person or provides him with powerful means.

In the term: from Shia, a general and specific definition is provided:

General definition: Throughout history, various terms and definitions have been used to define Shia. Some of them are:

- The one who puts Imam Ali before Uthman (Jahez Mu'tazili)

- One who believes in the precedence and superiority of Imam Ali over other companions and also believes in the existence of a text over his Imamate. (Sheikh Mofid)

- Those who consider the succession of the Prophet as the exclusive right of the Prophet's family and follow the school of Ahl al-Bayt in the teachings of Islam. (Allameh Tabatabai)

Special definition: Sheikh Mofid in the definition of Imamiyya says: An imam of a religion is one who:

- Believe in the necessity of Imamate and its existence at any time.

- To consider the clear text on the Imam and infallibility and perfection obligatory for him.

- A: Believes in the continuity and monopoly of Imamate in the children of Imam Hussein and connects the line of Imamate to Imam Reza. Because all Shiites believe in the continuation of the Shiite Imamate until Imam Reza and after him believe in its continuation until the twelfth Imam of Yazd. (Introduction to the Shiite sect, Mehdi Farmanian, p. 21)

Monitoring

- Supervision In Arabic literature, the noun masdar comes from the root of opinion, which means to comment along with reflection and accuracy in something. And an observer is someone who looks with a sharp nose and is free from slander.

- Some have considered the process of analogy between (was and should be) as a criterion for definition.) Supervision is an activity that compares musts with beings, desirables with beings, and predictions with actions, and the result of this comparison is a clear 
picture. The similarities or differences between these two groups of factors will be provided to the managers of the organization.

- Some have defined oversight of the operational set in compliance with the rules in order to ensure that objectives are achieved: Oversight is the set of operations in which the degree of compliance Individuals' performance is measured by rules and regulations to ensure that the performance conforms to the desired goals.

Research questions and hypotheses

Main questions:

Distribution and monitoring of power and mechanisms for increasing and efficiency of power in Shiite political thought

Sub-questions:

- How is power monitored in Shiite political thought?

- How is the distribution of power in Shiite political thought?

- What are the mechanisms to increase political power and its efficiency in Islamic society?

theories:

The issue of corruption and abuse of power and authority by the people in power and their turning to tyranny, oppression, tyranny, amassing wealth and is one of the issues that have long been on the minds of thinkers. On the one hand, they thought that the basis of the government and the central government, which manages the affairs of the people, is a necessity of a society, and a society without a government leads to chaos and security is taken away from the society. And this issue requires countless corruptions and losses and a lot of damage to all sections of society, and on the other hand, the government gives those in power the ability to exercise their will on the people, their actions to And this is because the rulers in the position of exercising power are faced with options that may not have rational, logical and religious justification. And it is possible for them to perform intelligent actions at any time. Because power and possibilities put man in danger of slipping and lead to corruption. The greater the limit of this power and authority, the greater the risk of slipping and falling. The need to monitor power and its quality and the distribution of power in government is one of the most fundamental questions in the field of governance and political philosophy.

There are three theories in a broad category of the origin of political power. One is the theory that the origin of political power is purely divine. Another introduces the people and their election as the only source of legitimacy of political power, and the third theory believes that the origin of political power is due to divine sovereignty, which is exercised through the free will of the people or their elected representatives.

The security of the government against corruption has been one of the major issues raised among political and governmental scientists, and one of the most important dimensions to achieve this is to limit and control the rebellious manifestations of power. The control of political power should be mainly in the two areas of internal control (internal characteristics such as piety, justice, attention to moral conscience) and external control, which will be the function of political power.

Also, in order to prevent corruption in power, according to the theory of separation of powers, the division of labor and distribution of duties should be emphasized, and this will be in order to prevent the concentration of power in the hands of a small group and a specific person.

In Shiite political thought, special mechanisms have been considered to increase and strengthen political power, and in this regard, strengthening both the value (divine-religious), popular (social) 
dimensions of the Islamic system will increase and increase political power as a component. Such as: relying on the expert opinions of advisory groups, correct policy-making and decision-making, the rotation of power in the political system, relying on new scientific achievements and monitoring power.

\section{Background research}

Books, articles, treatises, and dissertations have been written on this subject, each of which has studied the subject of political power from a specific aspect.

1. The book Supervision of Power in Political Jurisprudence by Dr. Sajjad Izadehi, which mostly refers to the narrative arguments in proving and supervising power. The book of thematic interpretation of the message of the Qur'an by Ayatollah Makarem Shirazi, in the tenth volume of which deals with the subject of the dimensions of the Islamic government.

2. The book of Ayatollah Khamenei's political thought by Mohammad Mehdi Ismaili, which only analyzes His Holiness's political thought on the generalities of government and power.

3. The book Political Power from the Perspective of the Holy Quran by Seyyed Kazem Mir Bagheri has only studied the verses about political power.

4. The book The Relationship between Power and Justice in Political Jurisprudence by Gholam Sarvar Akhlaqi is merely an attempt to define power, justice and politics from the perspective of non-Muslim and Muslim scholars, especially Islamic jurists.

5. The book Theory of Power is taken from the Quran and Sunnah by Mohammad Hadi Mofteh, which deals with the origin, structure and application of power.

6. The book Factors of National Authority from the Perspective of the Quran and Hadith by Mohammad Mahmoudi Khorasani, which deals with various factors that cause the authority of the Islamic system from the perspective of the Quran and hadiths.

7. All the above books try to examine the jurisprudential principles of power from a certain angle, either from the point of view of the Qur'an or from the point of view of the Sunnah, or only from the point of view of Muslim jurists. The perspective of the Qur'an and the traditions and sayings of the jurists and the rational arguments have not been discussed.

Among the articles and treatises in this field, the following can be mentioned:

- A Study of the Concept of Political Power by Ismail Ajrlou and Daniel Taheri (a work of the Guardian Council Research Institute)

- The foundations of the legitimacy of political power in the political thought of Islam by Abdullah Mir Ghiasi

- Power from the perspective of Imam Khomeini Rezvan Allah Almighty against the work of Mohammad Bavi

- Political Thought in the Qur'an by Najaf Lakzai

- Objectives and function of desirable political power from the perspective of the Holy Quran by Seyyed Kazem Seyyed Bagheri and Batool Mollashfiei

- Imam Khomeini and the issue of monitoring and limiting political power by Sajjad Izadhi

- Recognizing the concept of power in Imam Khomeini's political thought by Seyyed Abdul Hussein Hojjatzadeh

- Mechanisms for increasing the efficiency of political power in the Islamic Republic of Iran by Mohammad Ali Hosseinzadeh

- Jurisprudential principles of the method of producing power in government Greetings by Seyed Safoura Mohammadi 
All articles, dissertations and dissertations have discussed only specific topics and the topics discussed do not have the comprehensiveness of the subject of my dissertation. For example, in the article Examining the Concept of Political Power, the concepts of public law have been tried. And the rulers are discussed in it.

\section{Research Methodology}

Depending on the subject of the research, the method of collecting materials in an analytical and descriptive manner and by studying valid sources in the library and if possible the interview method will be on the agenda so that first the sources are studied and then analyzed., This study aims to achieve results in the end and make suggestions to improve the current situation; Therefore, first the required resources from various sources (presence in the library, digital libraries, existing software such as comprehensive Ahl al-Bayt and Shiite history and existing articles, treatises and dissertations, selected and after studying and separating the required materials, taking notes $\neg$ The required resources will be obtained and then completed as a complete research, which will include indirect methods such as the use of articles and scientific research to collect data. Data collection from scientific and research books and articles will be used.

\section{History of Shiite political ideas}

The first and perhaps most important finding of the study of the relationship between Shi'ism and politics in history is that we cannot speak of history as a whole as a Shi'a or as a single line under the title of the relationship between Shi'ism and politics. Throughout history, we have had various Shiite currents, each of which has established a certain relationship with politics over a period of time. Therefore, we must talk about the relationship of each of these currents with politics in a certain place and time and avoid generalization.

With the absence of the theory of the rule of law in history, two currents are formed among the Shiites. The existence of the idea of absence and the government's exclusive right to the infallible, on the one hand, leads to the formation of a kind of isolationism and political passivity among some Shiite currents, mainly the Imami jurisprudential current. Due to the existence of the theory of government, this current does not formulate political theory for the days of absence, the jurisprudence of this current does not deal with public spheres and remains limited to private spheres. In practice, this movement also sometimes suffers from a kind of pragmatism due to expediency and establishes relations and cooperation with governments. But in parallel with this current, which can be referred to as Shiite or pro-regime by using Ali Shariati's typologies, there is another current that refuses to compromise with governments and does not withdraw from politics. Shiite movements or, in Sharia terms, Shiite movements should be categorized here. Shiite uprisings, including the uprising of Mukhtar, Zayd ibn Ali, Yahya ibn Zayd, etc., which are mentioned in the book "Shiite uprisings" by Abu Dharr Karamullahi, as well as movements such as Harufiyeh, Sarbdariyeh, Moshasheiyeh, etc. are all below. Shiite movements are classified. It seems that the movement of Shiite jurists in deriving religious and political laws has been for the honor of the religion and the interest of the Shiite community, and after this transformation, the jurist has a higher responsibility in the Shiite community and becomes a religious ruler who is prudent. He is in charge of the public affairs of the people according to the rules of Sharia. The implication of this statement is that non-jurists do not have the ability to create a standard concept for the establishment of a sharia state that can be the basis of the Shiite social movement in worship and trade and social relations at different historical stages.

Then, from this point of view, the experiences of the connection between the jurist and the state are read from the jurisprudential point of view. And this study, especially after the coordination and accompaniment of theology and jurisprudence on the issue of government and Imamate, 
which both dealt with and jurisprudence, became a common chapter in both theological and jurisprudential fields, finds more importance. Of course, based on the data of the history of jurisprudence and theology, these two sciences were usually collected in jurists. However, in special historical magazines, such as the Safavid era, theology has been separated from jurisprudence to some extent, and naturally the jurist has been separated from the theologian. The achievement of this historical study will show us how the jurist, in accordance with his time, has devised a conceptualization of politics and its connection with it from a jurisprudential point of view. Interestingly, there has always been a negative or positive relationship between the jurisprudent and the ruling political system, until finally the jurisprudent has been able, in the broadest jurisprudential-political view, to conceptualize the formation of the government only in his jurisdiction. Certainly, the state that the jurist describes is not similar to national, tribal, group, and دولت governments; Rather, it is a state equal to the jurisprudential standards; That is, those who in jurisprudence give this guardianship over the government to the jurist. In conclusion, however, it should be said that all of us today face the effects and consequences of the establishment of a religious government in various areas of our social life, and that is why studying the relationship between "Shiism, power and politics" is an urgent necessity for us. These studies have not yet found a proper place in our sociology.

\section{Jurisprudential principles of controlling power from the perspective of Imam Khomeini}

Thanks to the Islamic Revolution of Iran, with the irreplaceable leadership of Imam Khomeini and the establishment of the Islamic Republic, the field of practical and objective tests was provided to enjoy the blessings of power and rebellion and oppression of the rulers of the nation by enjoying an Islamic government and its blessings. Don't be. Jurisprudence, which in the view of Imam Khomeini (ra): is a real and complete theory of human administration from the cradle to the grave, as it has principles to prove the principle of government; the door It also lays the foundations for controlling and supervising those in power, and adorning the sphere of politics with desirable qualities, and making rulers who are servants and trustees; This important issue has been studied in the research of the honorable researcher Mr. Hojjatoleslam and Muslims Seyed Sajjad Izadhi. However, the history of Shiite political jurisprudence has not discussed the ideal government and rule of Shiite jurisprudence due to the non-recognition of the Shiite religion and the dominance of the atmosphere of Taqiyya over Shiite scholars and jurists. But at the same time, the words and phrases of Shiite jurists are full of issues and foundations that can be considered a system for monitoring, limiting and controlling political power. These principles are rooted in the early history of Islam and according to it and according to Islamic teachings, the rulers did not consider themselves infallible and considered themselves mainly accountable to the people. Many examples of this type of government can be seen in the era of the rule of the Holy Prophet of Islam, Imam Ali (AS) and the first two caliphs. However, this logic did not last long and the rulers of the Islamic land, who also bore the name of Muslim, did not consider themselves accountable to the people and gradually turned away from the original Islam and turned to corruption, proliferation and power. (Seyed Sajjad Izadhi, Bita)

\section{The need for separation of powers}

From the point of view of power thinkers, the facilities available to those in power have long provided the ground for their approach to corruption and tyranny, and prepare the ground for the abuse of power. Hence, on the one hand, they considered the necessity of individual rule to eliminate chaos and create security from the necessities of society, and on the other hand, they were afraid of the unlimited power of the rulers, seeking to recognize the nature of power and its impact. Those who came to power, while entrusting the affairs of society to the ruler, put the need to limit power and monitor it on their agenda, they believed. Experience has shown that every 
human being with power abuses his power. It tends to move forward to the point of collision. (Abolfazl Ghazi, Requirements of Constitutional Rights, p. 30).

Given that the great power and possibilities of the rulers, who are allowed to interfere in largescale affairs, pave the way for corruption and abuse, which, if it does not contaminate them with tyranny, will certainly provide a wider ground for their corruption, so discuss the necessity. Supervision of power and its quality is one of the most fundamental questions in the field of governance and political philosophy. Each individual, group or school has answered this question, proposing a solution and mechanism that is useful for limiting power. has done. The consequence of the functioning of Western authoritarian regimes, limiting the sphere of power of rulers, has become the concern of thinkers, while separating three different areas of legislation, law enforcement and judging according to the law that was traditionally in the hands of each ruler. $\mathrm{He}$ enforced it and judged according to his own law, which in the first stage gave the legislature an independent group, and finally left the judgment to experts, only the implementation of the law. Considered to be the responsibility of the ruler. Known for its logic of distribution and separation of powers, this issue is one of the ways of limiting and skill of power and was initially formally raised by Montesquieu and later accepted by Western political systems as a method. Power control and control were favored and acted upon. This theory sought to decentralize political power, emphasizing the distribution of political power between the executive, the legislature, and the judiciary, and to divide power from one person into three opposing powers so that each power $\neg$ Monitor each other and control the power of the other power.

In this regard, the political system of Islam has not considered power as an inherently evil thing, has considered it as a basis for the implementation of divine commands, and therefore does not shy away from the category of government. At the same time, it emphasizes the provision of power for abuse. دDehd: I am the property of influence and I am the tyrant for destruction. Whoever becomes the ruler becomes tyrannical and whoever practices tyranny will perish. (Nahj al-Balaghah, Wisdom 252). According to this meaning, Imam Ali (AS) has recommended the limitation and control of power in line with the principles and teachings of the Shiites, and has used it in line with internal and external strategies. On this basis, the Shiite political system seeks to control power as much as possible according to a specific logic, or by imposing attributes on the rulers, establishing a cultured and pious leadership on the throne of power, thus establishing internal control over the established political system. Establish or, by redefining the regulatory system, actively and permanently limit and control political power.

\section{Separation of powers}

In contemporary political philosophy, the concern for the control of political power usually manifests itself in the form of the theory of separation of powers. And although the category of control of political power is not limited to a specific time and the issue of separation of powers, the history of this issue must be traced back to the Middle Ages. In which an authoritarian government, under the auspices of the church, became tyrannical and considered itself the authority of the people and based on their legitimacy to divine appointment, considered themselves the successors of God and therefore, on behalf of God and with the permission of the church members over the people. They ruled. That is why they never held themselves accountable to the people.

The concern for the control of power in the form of the logic of distribution and separation of powers was first and formally raised by Montesquieu. It was later accepted by Western political systems and adopted as a method of controlling and controlling power. This theory sought to decentralize political power by emphasizing austerity Political forces Divide power between the executive, the legislature, and the judiciary from one person to three branches that exist within each other, so that each power oversees the other and controls the power of the other. 
It is natural to discuss the issue of separation of powers, which has been raised in political philosophy since the Middle Ages. It mainly pays attention to external supervision and is subject to the conditions of its time and has been proposed in response to the actions of tyrants of the time. The Shiite political system has considered a solution for monitoring and limiting power, which in addition to external monitoring, has considered other components such as internal monitoring, including concepts such as enjoining the good and forbidding the evil, advice, criticism.

\section{Conditions of those in power in order to gain power}

In the monitoring phase of gaining power, Shiite jurisprudence believes that the Shiite political system has regulated the process of gaining power and commented on it, in this regard, the government has largely distanced itself from corruption and corruption. This process can ensure the health of the political system and government, by defining characteristics for those in power in the beginning. That the ruler or agent of the Islamic system, if attacked, will distance himself from corruption and will avoid abusing power. In other words, making it obligatory for those in power to acquire these attributes at the stage of gaining power is for the purpose of institutional oversight, it will keep evil-doers and evil-minded people from relying on the power, and only those in power will be empowered. ابتدا Basic in this regard, less prone to corruption and abuse.

\section{Monitoring in the power cycle}

Considering that we considered supervision in all stages of the government of acquisition, actions, distribution and current circulation, it should be said that not only supervision is in the stage of power circulation, but this stage is one of the most important stages in which the category of supervision should be. Ongoing, the lack of oversight at this stage would be tantamount to the lack of oversight principle. Supervision in this stage, which occurs in the form of impeachment, dismissal and removal from power, is a guarantee for supervision in the previous three stages, because if the rulers do not accept the category of supervision, they should be removed from office. Someone else to replace them. Of course, this issue is different based on different readings of the political system, it finds different approaches, but it goes without saying that more understanding of supervision at this stage should be sought in different types of Shiite political system in the era of absence.

\section{Supervision in the power distribution phase}

In the post-medieval centuries, with the development of freedoms and the restoration of the social character of nations in response to the tyranny of the rulers, the government took on a new form; In other words, at the request of the people in the beginning, the absolute concentration of power in the hands of the rulers was abolished and with the transfer of legislative power to the people, the system of constitutional monarchy was established and the ruling power (Shah) was limited by parliamentary legislation. In the later stages, the judiciary also freed itself from the concentration of power and gained independence, and since the system of social affairs is confined to the three axes of legislation, implementation and judiciary,

The separation of powers took place in the form of three branches: the legislature, the judiciary and the executive, and this is because in the general division of governmental functions, human beings are faced with three types of duties which are divided according to the essential division; From law making, law enforcement and litigation according to law. These three, while differentiating from each other, cover a wide range of society, and it can be said that none of the dimensions, behaviors and social relations are outside the set of these three pillars. (Mohammad Hossein Eskandari, p. 197) 
The prevalence of the phenomenon of separation of powers in the common sense owes more than anyone to Montesquieu; He is a French thinker who proposed this hypothesis in order to study and protect individual and political freedoms, and in fact, linked the protection of this thinker's freedom to the theory of separation of powers: the study of the issue of political freedom and its relations with the government. Not enough. It should also be studied in its relationships with people. Freedom in this case is achieved by the division of the three forces. (Translated by Ali Akbar Mohtadi, p. 1)

\section{Types of monitoring}

Monitoring, like the various meanings it provides, comes in many forms and instances. According to some cases, it is enough for the observer to be aware of the wrongdoing issues. The observer should only report deviations to the responsible institutions, but the correctness or incorrectness of those actions is not within his / her discretion and understanding. He must report what he has observed.

According to some others, although the observer still does not interfere in the prohibition of improper actions, but his understanding of the correctness or invalidity of these actions was valid. The person who appointed him, considered his understanding in this regard as valid.

According to the first type of supervision, which is sometimes called exploratory supervision, merely informing the observer in the desired area about the actions is sufficient. According to this type of supervision, the agent has no obligation to the supervisor, although he must act according to regulations. Inform the supervisor.

If this meaning of monitoring in the field of politics is also used in this way (this type of monitoring is a process

It is said that the supervisor should only be aware of the situation that the executors are committing and then report what he has observed to another authority without taking any action and approving or rejecting the execution.

In exploratory supervision, the observer should only report the case according to the set criteria, his point of view and opinion have no effect on recognizing the violation. In the second type of supervision, which is also called approval, the observer, in addition to obtaining information, approves. And he also asks for an opinion, which means that in addition to being able to issue a verdict, his verdict is valid and legal actions without His permission and consent will not be valid.

\section{Evidence of monitoring}

The issue of controlling and controlling power is not an imported matter, it has not come to Islamic countries from Western societies; it is a matter arising from Islamic arguments and jurisprudence that is rooted in the teachings of Islam (the Book of God, the Sunnah of the Infallibles and human intellect).

\section{Quran}

Although the principle of controlling political power is not directly discussed in the divine book and the divine book is not a detailed discussion of such issues, but the discussion and principles of control, control and limitation of power can be seen in the form of many verses. Either in the field of prevention of corruption and abuse or criteria for limiting power, has been stated. Verses can be examined in terms of evidence and principles of monitoring. 


\section{Saint}

One of the original sources of control and control of power is the constant life of the infallibles. Considering that the discussion of supervision is mainly about the government and rulers. In this regard, we can refer to the life of the Holy Prophet (PBUH) and Imam Ali (AS). This view is sometimes mentioned in the words of all the Ahl al-Bayt. What can be summarized in this regard is that, firstly, the Prophet and the Imams not only considered tyranny and absolute rule unquestionably negative, but also considered themselves superior to Unbeknownst to the law, they held themselves accountable for their actions and deeds. Some of the solutions mentioned in the tradition of the infallibles in this regard are as follows:

- The rulers consult with the people

- Enjoining the good and forbidding the evil

- Criticism of the rulers in the direction of direct popular control

- Mechanisms to increase the efficiency of political power

- In order to study the mechanisms of increasing political power and effective power

- It is in internal and external dimensions and in this regard, recognizing the effective factors and variables in

- Reducing and inefficiency of political power is also necessary to prevent recession, decline and decline.

- In the minds of the rulers, supporting the government means supporting the political system.

- Without playing an influential role, the government does not take any important action in society, either within or within the system

- International is not possible. Therefore, the Islamic State has a duty to increase and efficient mechanisms

- Provided Islamic power. This can be seen as a platform for playing the role of political power

- Effective against threats.

- Imam Khomeini believed that the government is considered as a manifestation of political power in society and to any extent

- Increase the power of government, provide more ground for the manifestation of national will in the international system; Because

- The government has a duty to create conditions that ensure the maximum interests of the country. A government that conditions

- More inclusive action, naturally more motivated and capable of securing national interests

- is. In this process, the government's main commitment is to maximize national interests to increase political power.

- And is an international country. If the government has effective domestic support, then somehow

- It will be more effective in securing the national interest of the country because the main commitment of governments to the interests of society.

- The more power a government has, the more successful it will be in securing national interests

- Increases and we also in this paper seek to identify the mechanisms and methods of the team that can

- The most appropriate and the best and most political power and efficiency for the Islamic system and its goals 
- Mechanisms for increasing power and efficiency are divided into two parts: internal or internal mechanisms and external and external (international) mechanisms. Each of them according to the four important areas of society into political mechanisms, Cultural, economic and social are divided into:

- Promoting the legitimacy of political power

- Unification and consensus building in the society among the people

- Avoiding aristocracy

- Foresight and drawing a clear vision for society

- Creating political stability in society

- Growth and progress in science production

- The field of strong and powerful consultants

- Reasoning in society

- Democracy and people's participation in the growth of society

- Responding to people

- The existence of a party in the true sense

- Fight against corruption

\section{Conclusion}

The category of control and control of power is not an imported matter, it has not come to Islamic countries from Western societies; it is a matter arising from Islamic arguments and jurisprudence that is rooted in the teachings of Islam (God's book, the tradition of the infallibles and human intellect). It can be divided into two types: internal and external monitoring

Internal oversight is necessary and the need arises from the fact that no matter how careful the design of external mechanisms is, it will still be incapable of comprehensive and final control over the governing body. Here if the person is able to comply with ethical standards and standards. However, the probability of error and deviation is reduced to a minimum. However, internal monitoring does not eliminate the need for external monitoring, nor the application of external control methods to take into account internal conditions and characteristics, but both are necessary to each other. And they must be considered in the structure of government. Therefore, the factors of power in various political, economic, cultural, military, etc. are numerous, but their position is not the same, but in such a way that some are more fundamental than others. National authority in any society is the result of different cultural, economic, social, political and military powers along with preserving the human dignity that they produce to make the power of society dynamic.

\section{References}

Abolfazl Ghazi, the requirements of constitutional rights.

Supervision of power in political jurisprudence, Seyed Sajjad Izdehi, 2010, Institute of Islamic Sciences and Culture

Thematic interpretation of the message of the Qur'an, Ayatollah Nasser Makarem Shirazi, 1989, Imam Amir Al-Momenin School

Political Thought of Ayatollah Khamenei, Mohammad Mehdi Esmaili, 1398, Software Movement

Political power from the perspective of the Holy Quran, Seyyed Kazem Mir Bagheri, 2011 
The relationship between power and justice in CIA jurisprudence Si, Ghulam Sarwar Akhlaqi, 1390, Mustafa Publishing

Theory of power taken from the Qur'an and Sunnah, Mohammad Hadi Mofteh, 1390, Qom Park

Factors of National Authority from the Perspective of Quran and Hadith, Mohammad Mahmoudi Khorasani, 2010, Ashna

Sahifa Noor, Seyyed Ruhollah Khomeini, Imam Khomeini Publishing Institute, 2000, Tehran

Comparison of language, Ibn Faris Ahmad Ibn Abi Al-Hussein, Dar Al-Jadeed, Beirut

A Study of the Concept of Political Power, Ismail Ajarl, Daniel Taheri (a work of the Guardian Council Research Institute)

Fundamentals of the Legitimacy of Political Power in Islamic Political Thought, Seyyed Abdullah Mir Ghiasi

Power from the perspective of Imam Khomeini, Mohammad Bavi

Political Thought in the Qur'an, Najaf Lakzai

Objectives and function of desirable political power from the perspective of the Holy Quran, Seyyed Kazem Seyyed Bagheri, Batool Mollashfiei

Imam Khomeini article and the issue of monitoring and limiting political power, Sajjad Izadhi

Recognition of the concept of power in the political thought of Imam Khomeini, Seyyed Abdolhossein Hojjatzadeh

Mechanisms for increasing the efficiency of political power in the Islamic Republic of Iran, Mohammad Ali Hosseinzadeh

Jurisprudential principles of the method of producing power in the Islamic state, Seyyed Safoura Mohammadi

An Introduction to Constitutional Rights, Mohammad Hossein Eskandari

Montesquieu, The Spirit of Laws, translated by Ali Akbar Mohtadi, $p$

Monitoring power from the perspective of the Qur'an, Journal of Political Science, No. 19, p. 104

Supervision and supervisory institutions, Mohsen Malek Afzali, p.21

Collection of works, Morteza Motahhari, vol. 12, p. 166 